\title{
Are Board Size And Ownership Structure Beneficial In Emerging Markets' Firms? Evidence From Jordan
}

Tariq Tawfeeq Yousif Alabdullah, University of Basrah, Iraq

\begin{abstract}
The present study aims to investigate the effect of board size and managerial ownership on firm performance in Jordan, based on agency. The current study examined cross sectional data to test all hypotheses through using statistical software, SPSS 20, to analyze data on a sample of 60 firms (service firms) in Jordan as one of emerging markets in Asia. Multiple regression analysis instruments were used to test the hypothesis regarding the effect of board size and managerial ownership on firm performance with the effect of firm size as a control variable. The data used in the current study is obtained from the annual reports issued by Amman Stock Exchange (ASE) for the year 2014. Accounting data is used in the current study for the purpose of measuring the performances represented by ROA and ROE. I find that measures of board size statistically affect ROA and ROE. Board size affects ROA and ROE positively while firm size has no effect on firm performance. Unfortunately, managerial ownership does not affect both ROA and ROE. The current study presents practical evidence to the policy makers, academic and all beneficiary parties in emerging markets, specifically Jordan.
\end{abstract}

Keywords: Board Size, Ownership Structure, Performance, Emerging Markets

\section{INTRODUCTION}

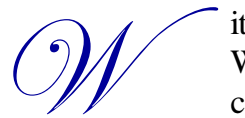
ith the appearance of the Asian financial crisis in 1997 and the recent crisis including Enron, WorldCom, and others, in America and Europe, confidence in legislative bodies, agencies and corporate institutions is all-time low (Alabdullah, Yahya, \& Ramayah, 2014). Such problems were highlighted during the crisis by several interested parties around the world. They tried to face such challenges through relying on corporate governance as a robust system to participate in solving these problems. Corporate governance mechanisms have developed as vital instruments over the last two decades. With the advent of recent global crisis, corporate governance has been recognized as an important system in enhancing firm performance (Ehikioya, 2009). In developed countries, there have been several considerable studies on corporate governance and corporate performance. Nevertheless, still the relative studies in developing countries, particularly in Jordan on the influence of corporate governance are little, scarce and rare (Al-Haddad, Alzurqan, \& Al_Sufy, 2011; Al-Khouri, 2006). Jordan as an emerging market is increasingly shifting from controlled to market based economy with market privatization of all companies listed at Amman Stock Exchange (Al-Najjar, 2010). Corporate governance now has become a norm in Jordan, where the first CG Code was published in 2009 as mentioned by (Abed, Al-Attar, \& Suwaidan, 2012). Yet, Jordan capital market and its economic situation are still weak, as revealed by The World Bank (2014) that non-financial sector represented by service and industrial companies faced a drop in Gross Domestic Product (GDP) in the last few years. Figure 1 illustrates this point in the Jordanian context. 
Figure 1. Non-Financial Sector (Share in GDP)

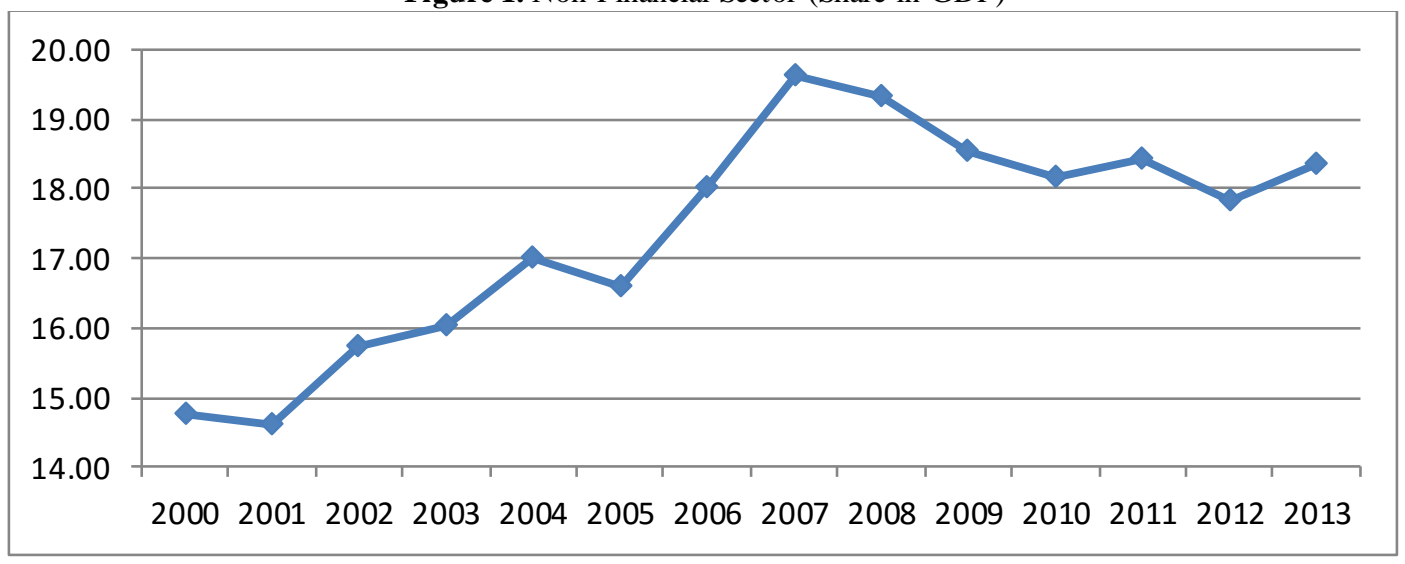

In addition, the application of corporate governance mechanisms in Jordanian listed companies is still in its initial stages, so they need more time for compliance with the corporate governance regulations (Abed et al., 2012). Moreover, companies in non-financial sector in Jordan suffered from poor performance as mentioned by (Alabdullah et al., 2014).

Based on the above explanation, the contribution of the current study lies in selecting service sector through its companies as one of the non-financial sectors in Jordan that faced and contributed to two kinds of decline; one is in the performance of its companies and the other in the Jordanian economy in general as mentioned by prior works in the literature and The World Bank. Thus, the current study aims at testing the impact of board size and ownership structure on firm performance in one of the emerging markets, namely Jordan. Furthermore, the significant role made by the current study is considered as an attempt to fill a gap in the previous studies by exploring the relationship between two important mechanisms of corporate governance with accounting based measurement (ROA and ROE). There is a scarcity in testing corporate governance in the Jordanian context, where, to the best knowledge of the researcher, there is no previous study that has investigated the variables of the current study in Jordanian service sector in the time that such a sector needs to be investigated by researchers to deal with its companies' problems. The data used in the current study is based on the recent one year, 2014 for the companies belonging to service sector and belonging to non-financial sector listed in Amman Stock Exchange (ASE) in Jordan.

In Jordanian context, Amman Stock Exchange (ASE) has made several changes in terms of regulations through issuing a corporate governance mechanism in 2009. However, due to the poor performance in the non-financial sector including service sectors, Jordan has faced several internal economic, busine ss and social challenges besides the global financial crisis, which call for the importance of identifying key factors influencing the firm's performance.

The remainder of the current study is organized in the following way. Section 2 shows briefly the literature review and research hypotheses and is followed by Section 3 which explains the sample and Methodology including the source of data collection and variables measurement. In Section 4, the result and discussion will be reviewed. Finally, Section 5 will be the conclusion of the study.

\section{LITERATURE REVIEW AND RESEARCH HYPOTHESES}

Board size is one of the vital elements of quality of corporate governance mechanisms that control the firm's business to ensure it is properly conducted by their agents to reduce agency problems (Mkrtchyan, 2013; Shleifer \& Vishny, 1997).

Thus, there is an agreement in the literature that smaller board size is considered to be further effective mechanism in achieving higher monitoring. In that, it has lesser disagreements among board of directors members, and are possibly to be more organized and efficient to carry out board of director functions, than larger board of directors 
(Jensen, 1993; Lipton \& Lorsch, 1992; Yermack, 1996). Moreover, it provides evidence of an inverse relationship between board of directors size and profitability, while (Baysinger \& Butler, 1985) and (Bhagat \& Black, 2001) find no meaningful relationship between board characteristics and company performance.

For example, studies done in developed countries, such as Eisenberg, Sundgren, and Wells (1998) and (Klein, 1998) find that there is a negative relationship between board size and ROA. Alternatively, other results in emerging markets admit that there is a positive relationship between board size and company performance. The results of such studies show that the larger the board leads to have expertise, knowledge and effectiveness; thus this will lead to better performance (Buniamin, Alrazi, Johari, \& Rahman, 2008). Moreover, Abor and Biekpe (2007) demonstrate that the large size of the board SMEs in Ghana is considered as one of the most vital mechanisms that leads to better firm performance. More specifically, in Jordanian non-financial sector, a study done by (Alabdullah et al., 2014), demonstrates that there is a positive relationship between board of director and firm performance.

The above review of related studies has shown that board size mechanism has either positive or negative relation with company performance depending on specific conditions of each market and time of the data. However, more studies have found a positive relation than the negative ones, especially in Jordan. For this reason, the current stu dy predicts that increasing board size will increase firm financial performance:

H1. There is a positive relationship between board size and ROA.

H2. There is a positive relationship between board size and ROE.

On the other hand, previous studies admitted the important role of managerial ownership as an important mechanism that elevates agency problems. (Jensen \& Meckling, 1976) show that agency costs will increase when shareholders hold a small proportion of firm's share because the agent (managers) in this case will use firm's assets to improve their benefits on the account of shareholders' wealth.

Previous studies have revealed findings that increasing managerial ownership in the firm is an important issue that decreases agency problems and pushes managers to promote firm performance, such as ROA and ROE ( (Klein, 1998; Kren \& Kerr, 1997). In Jordan context, a study conducted by (Alabdullah et al., 2014) shows that there is a positive relationship between managerial ownership and firm performance. Thus, the present study predicts that increasing managerial ownership is an important factor to increase firm performance. For this explanation, the following hypotheses were developed:

H3. There is a positive relationship between managerial ownership and ROA.

H4. There is a positive relationship between managerial ownership and ROE.

\section{SAMPLE AND METHODOLOGY}

\subsection{Source of Data Collection and Variables Measurement}

The current research investigates the association between two mechanisms of corporate governance represented by board size and managerial ownership, and firm performance expressed by ROA and ROE in Jordanian service sector. This study deals with a sample of companies belonging to service sector in Jordan as cross sectional study that its data are from the annual reports for the year 2014. The study chose companies listed on the Amman Stock Exchange as one of the largest stock markets in Asia. Jordan plays an important role as one of the important emerging markets, non- financial companies in Jordan (service companies). Nevertheless, such companies suffered from problems in firm performance specifically in the last few years.

This study measured financial performance via ROA and ROE. Corporate governance mechanisms namely: the board size BOD and managerial ownership (MOwner) are the independent variables that represented accounting based measurement for firm performance (ROA and ROE). In addition, firm size (Cosize) is the control variable. 
Table 1 shows the measurements summary of the variables.

Table 1. Summary of variables measurement

\begin{tabular}{|c|c|c|c|}
\hline NO & Variables & Acronym & Measurement \\
\hline \multicolumn{4}{|c|}{ Dependent Variable } \\
\hline 1 & Return on assets (\%) & ROA & $\begin{array}{l}\text { Return on assets, measured as the percentage of net income to } \\
\text { total assets }\end{array}$ \\
\hline 2 & Return on equity (\%) & ROE & $\begin{array}{l}\text { Return on equity, measured as a percentage of net income to } \\
\text { common equity }\end{array}$ \\
\hline \multicolumn{4}{|c|}{ Independent Variables } \\
\hline 3 & Board size & BOD & Board size is the total number of directors on the board. \\
\hline 4 & $\begin{array}{l}\text { Managerial ownership } \\
(\%)\end{array}$ & MOwner & $\begin{array}{l}\text { Managerial ownership is measured as the percentage of total } \\
\text { shares held by firm directors and officers. }\end{array}$ \\
\hline \multicolumn{4}{|c|}{ Control Variable } \\
\hline 5 & Firm Size (number) & Cosize & Natural logarithmic of the firm's total assets. \\
\hline
\end{tabular}

The models used in the current study included specific variables, which are also probably to have impact on the firm financial performance (ROA and ROE).

$$
\begin{aligned}
& R O A=\alpha+\beta_{1} B O B+B_{2} \text { MOwner }+\beta_{3} \text { Cosize }+\varepsilon \ldots \\
& R O E=\alpha+\beta_{1} B O B+B_{2} \text { MOwner }+\beta_{3} \text { Cosize }+\varepsilon \ldots
\end{aligned}
$$

\section{RESULTS AND DISCUSSIONS}

\subsection{Descriptive Analysis}

The descriptive analys is for the variables of the current study for the 60 companies belongs to service sector listed at Amman Stock Exchange through using descriptive statistics. Table 2 clarifies the distribution of variables. The results of descriptive statistics show that the mean of ROA of Jordanian service companies is $28.2 \%$ with a standard deviation of 1.762. Moreover, minimum rate of ROA in the Jordanian non-financial companies is $0.0 \%$ with a maximum level of ROA equal to $68.8 \%$. ROE showed that the mean of Jordanian service companies is $33.7 \%$ with 2.538 of standard deviation. In addition, minimum rate of ROE is $0.0 \%$ with highest maximum level of ROE equal to $12.5 \%$.

In Table 2, the descriptive analysis for all variables of the study and also the results show that the values for the kurtosis and skewness show that the sample of the study is normally distributed due to the accepted range of normality for both of them. (Brooks, 2014) explains that the normality of data could be achieved when standard kuartosis is within \pm 3 and standard skewness is \pm 1.96 .

Table 2. Descriptive Analy sis

\begin{tabular}{l|c|c|c|c|c|c}
\hline \multicolumn{1}{c}{ Variables } & Mean & Std. Dev & Minimum & Maximum & Skewness & Kurtosis \\
\hline BOD & 8.95 & 2.977 & 4 & 15 & .218 & -.824 \\
\hline MOwner & .494 & .231 & .000 & .827 & -.567 & -.416 \\
\hline ROA & 2.829 & 1.762 & .00 & 6.88 & .656 & -.249 \\
\hline ROE & 3.376 & 2.538 & .000 & 12.50 & 1.045 & 1.731 \\
\hline Cosize & 7.351 & .607 & 5.96 & 8.96 & .153 & -.061 \\
\hline
\end{tabular}

\subsection{Correlation Analysis}

The correlation analysis between the variables of the current study is shown in Table 3. The result reveals that board size (BOD) has a positive relationship with ROA and ROE with value (ROA .631), (ROE .444). In addition, 
managerial ownership has also a positive relationship with ROE with value (ROE .003), but negative with ROA with value (ROA -.048). The table reveals that board size has a highly positive relationship with ROA with value .631 .

Table 3. Correlations between variables

\begin{tabular}{c|c|c|c|c|c}
\hline & BOD & MOwner & ROA & ROE & Cosize \\
\hline BOD & 1 & & & & \\
\hline MOwner & $.308^{*}$ & 1 & & & \\
\hline ROA & $.631^{* *}$ & -.048 & 1 & & \\
\hline ROE & $.444^{* *}$ & .003 & $.675^{* *}$ & 1 & 1 \\
\hline Cosize & .231 & -.068 & -.118 & -.027 & 1 \\
\hline
\end{tabular}

Level of significance $* \mathrm{p}<0.05, * * \mathrm{p}<0.01$

\subsection{Multiple Linear Regression Analysis}

Linear regression analysis is applied in this study to determine the effect and direction of the relationship between the independent and dependent variables as a method used in the studies and science disciplines.

\subsubsection{Regression Results of Model 1 (Based on firm performance measured by ROA)}

Model 1 as explained above is as follows:

$$
R O A=\alpha+\beta_{1} B O B+B_{2} \text { MOwner }+\beta_{3} \text { Cosize }+\varepsilon
$$

As shown in Table 4, the results of regression analysis reveal that $\mathrm{R}$ square value is .424 for ROA. It means that $\mathrm{R}$ square value explains $42 \%$ of the independent variables (BOD and MOwner) on the dependent one ROA.

Table 4. R Square of ROA

\begin{tabular}{c|c}
\hline Model & Market share \\
\hline R Square & .424 \\
\hline Sig F Change & .000 \\
\hline
\end{tabular}

In Table 5, multiple regression analysis was run between all the independent variables, control variable, and the dependent variable of ROA.

Table 5. Regression statistical analy sis

\begin{tabular}{c|c|cc}
\hline & ROA & & \\
\hline & S. Coefficients & & Sig. \\
\hline Variables & Beta & t- value & .000 \\
\hline BOD & $.696^{* *}$ & 6.296 & .121 \\
\hline MOwner & -.170 & -1.574 & .609 \\
\hline Cosize & -.054 & -.515 & \\
\hline
\end{tabular}

Level of significance $* \mathrm{p}<0.05, * * p<0.01$

The results of regression reveal that Cosize has no relationship with ROA $(\beta=-.054, \mathrm{P}>0.1)$. Furthermore, test hypotheses (H1 and H2) are shown in Table 5. There is a significant positive relationship between board size (BOD) and ROA $(\beta=.696, \mathrm{P}<0.1)$. This indicates that the financial performance (ROA) is influenced by board size in service companies listed in ASE. This result is in line with what has been proposed in the current study. The study can deduct significant relationship between board size and ROA. This result is consistent with p revious studies that were done in both developed and developing countries (Adams \& Mehran, 2005; Belkhir, 2009; Fauzi \& Locke, 2012). They mentioned that there a positive relationship between board size and ROA. Thus, hypothesis H1 (There is a positive relationship between board size and ROA) is supported.

In respect to the relationship between managerial ownership (MOwner) and financial performance (ROA), the test 
hypotheses found an insignificant relationship between them at $\beta=-.170, \mathrm{P}>0.1$. This is not in line with $\mathrm{H} 2$ (There is a positive relationship between managerial ownership and ROA). Therefore, hypothesis $\mathrm{H} 2$ is not supported. Nonetheless, this result is in line with some of previous studies (Mashayekhi\& Bazaz, 2008).

\subsubsection{Regression Results of Model 2 (Based on ROE)}

Model 2 as explained above is as follows:

$$
R O E=\alpha+\beta_{1} B O B+B_{2} \text { MOwner }+\beta_{3} \text { Cosize }+\varepsilon
$$

In Table 6, regression results show that $\mathrm{R}$ square value is .242 for ROE. This means that $\mathrm{R}$ square value is explaining $24 \%$ of the independent variables (BOD and MOwner) on the dependent one (ROE).

Table 6. R Square of ROE

\begin{tabular}{cc}
\hline Model & Market share \\
\hline R Square & .242 \\
\hline Sig F Change & .000 \\
\hline
\end{tabular}

In Table 7, multiple regression analysis was run between all the independent variables, control variable, and the dependent variable of ROE. As shown below:

Table 7. Regression statistical analy sis

\begin{tabular}{c|c|c|c}
\hline & ROE & & \\
\hline & S. Coefficients & t- value & Sig. \\
\hline Variables & Beta & 4.218 & .000 \\
\hline BOD & $.535^{* *}$ & -1.396 & .168 \\
\hline MOwner & -.173 & -1.345 & .184 \\
\hline Cosize & -.163 & & \\
\hline
\end{tabular}

Level of significance $* \mathrm{p}<0.05, * * \mathrm{p}<0.01$

The results of regression reveal that Cosize has no relationship with $\operatorname{ROE}(\beta=-.163, \mathrm{P}>0.1)$. In addition, test hypotheses ( $\mathrm{H} 1$ and $\mathrm{H} 2$ ) also is shown in Table 7. There is a strong significant positive relationship between board size (BOD) and $\operatorname{ROE}(\beta=.535, \mathrm{P}<0.1)$. This indicates that the financial performance (ROE) is influenced by board size in the companies belonging to service sector in ASE. This result is in line with what has been proposed in the present study. The study can deduct significant relationship between board size and ROE. This result is unlike the results of previous studies that were done in the literature (Beiner, Drobetz, Schmid, \& Zimmermann, 2004; Pathan, Skully, \& Wickramanayake, 2007). They mentioned that there is a negative relationship between board size and ROA. Nevertheless, the result is in line with hypothesis H3: (There is a positive relationship between board size and ROE). Thus, H3 is supported.

Regarding the relationship between managerial ownership (MOwner) and financial performance (ROE), the test hypotheses found an insignificant relationship between them at $\beta=-.173, \mathrm{P}>0.1$. This is not in line with H4: (There is a positive relationship between managerial ownership and ROE). Therefore, hypothesis H4 is not supported.

\section{CONCLUSION}

Recently, corporate governance system has become a very vital issue to the corporation including non-financial sector and its performance. The business world has faced many scandals and failures at the level of all sectors such as Enron and Arthur Andersen and Marconi. Such scandals and others have brought about a shock for both developed and developing economies and given so much attention to investors and other stakeholders to beware of dealing with corporations, within non-financial sector, which have poor level of corporate governance. 
Several studies have dealt with the association between corporate governance and firm performance; however, it should be noted that while the argument over corporate governance mechanisms role has been rich in rhetoric, there have been a few empirical studies that brought to bear on investigating the relationship between corporate governance and firm performance by choosing ROA and ROE as a measurement of firm financial performance in dealing with service Jordanian companies. This study uses Jordan data to analyze whether companies performed more when they have large board size and higher managerial ownership. In that, this study investigates the relationship of the firms' internal corporate governance mechanism represented by two of such internal mechanisms which are board size and managerial ownership, and their relationship with Jordanian Companies' Financial Performance.

The results show that larger board size has a positive impact on firm performance with its two measurements: ROA and ROE. However, there was no relationship between managerial ownership and firm performance. This means that managerial ownership is not matter in service companies in Jordanian context. The current study recommended the future research to investigate these two mechanisms with industrial sector as it belongs to non-financial sector too because both service and industrial companies belonging to the non-financial sector have faced problems as mentioned by The World Bank indicators and also by the results shown in the previous studies.

\section{AUTHOR BIOGRAPHY}

Tariq Tawfeeq Yousif Alabdullah, Ph.D. is a lecturer at Accounting section, College of Administration and Economics, University of Basrah, Iraq. His research interest is in the areas of Corporate Governance and Firm Performance. His Ph.D. in Accounting from Univers iti Sains Malaysia (USM). He has published several papers in international journals and proceedings and presented papers at international conferences in Malaysia, USA, Germany, and Italy. Email: tariqtariq1984@gmail.com

\section{REFERENCES}

Abed, S., Al-Attar, A., \& Suwaidan, M. (2012). Corporate Governance and Earnings Management: Jordanian Evidence. International Business Research, 5(1), 216-225.

Abor, J., \& Biekpe, N. (2007). Corporate governance, ownership structure and performance of SM Es in Ghana: implications for financing opportunities. Corporate Governance, 7(3), 288-300. doi: 10.1108/14720700710756562

Adams, R. B., \& Mehran, H. (2005). Corporate performance, board structure and its determinants in the banking industry. Paper presented at the EFA 2005 Moscow meetings.

Al-Haddad, W., Alzurqan, S. T., \& Al_Sufy, F. (2011). The Effect of Corporate Governance on the Performance of Jordanian Industrial Companies: An empirical study on Amman Stock Exchange. International Journal of Humanities and Social Science, 1(4), 55-69.

Al-Khouri, R. (2006). Corporate Governance and Firms Value in Emerging Markets: The Case of Jordan. Journal of Transnational Management, 12(1), 25-49.

Al-Najjar, B. (2010). Corporate governance and institutional ownership: evidence from Jordan. Corporate Governance, 10(2), 176-190. doi: 10.1108/14720701011035693

Alabdullah, T. T. Y., Yahya, S., \& Ramayah, T. (2014). Corporate Governance Mechanisms and Jordanian Companies' Financial Performance. Asian Social Science, 10(22), p247.

Bay singer, B. D., \& Butler, H. N. (1985). Corporate governance and the board of directors: Performance effects of changes in board composition. Journal of Law, Economics, \& Organization, 1(1), 101-124.

Beiner, S., Drobetz, W., Schmid, F., \& Zimmermann, H. (2004). Is board size an independent corporate governance mechanism? Kyklos, 57(3), 327-356.

Belkhir, M. (2009). Board of directors' size and performance in the banking industry. International Journal of Managerial Finance, 5(2), 201-221. doi: 10.1108/17439130910947903

Bhagat, S., \& Black, B. (2001). Non-Correlation between Board Independence and Long-Term Firm Performance. . Journal of Corporation Law, 27, 231-273.

Brooks, C. (2014). Introductory econometrics for finance: Cambridge university press.

Buniamin, S., Alrazi, B., Johari, N. H., \& Rahman, N. R. A. (2008). An investigation of the association between corporate governance and environmental reporting in Malaysia. Asian Journal of Business and Accounting, 1(2), 65-88.

Ehikioya, B. I. (2009). Corporate governance structure and firm performance in developing economies: evidence from Nigeria. Corporate Governance, 9(3), 231-243. doi: 10.1108/14720700910964307

Eisenberg, T., Sundgren, S., \& Wells, M. T. (1998). Larger board size and decreasing firm value in small firms. Journal of Financial Economics, 48(1), 35-54. 
Fauzi, F., \& Locke, S. (2012). Board structure, ownership structure and firm performance: A study of New Zealand listed-firms. Jensen, M. C. (1993). The modern industrial revolution, exit, and the failure of internal control sy stems. the Journal of Finance, $48(3), 831-880$.

Jensen, M.C., \& Meckling, W. H. (1976). Theory of the firm: Managerial behavior, agency costs and ownership struct ure. Journal of financial economics, 3(4), 305-360.

Klein, A. (1998). Firm Performance and Board Committee Structure 1. The Journal of Law and Economics, 41(1), $275-304$.

Kren, L., \& Kerr, J. L. (1997). The Effects of Outside Directors and Board Shareholdings on the Relation Between Chief Executive Compensation and Firm Performance. Accounting and Business Research, 27(4), 297-309. doi: 10.1080/00014788.1997.9729556

Lipton, M., \& Lorsch, J. W. (1992). A modest proposal for improved corporate governance. The Business Lawyer, 59-77.

Mashayekhi, B., \& Bazaz, M.S. (2008). Corporate governance and firm performance in Iran. Journal of Contemporary Accounting \& Economics, 4(2), 156-172.

Mkrtchy an, A. (2013). The Effect of Director Expertise on Acquisition Performance. Available at SSRN 2147169.

Pathan, S., Skully, M., \& Wickramanay ake, J. (2007). Board size, independence and performance: an analy sis of Thai banks. Asia-Pacific Financial Markets, 14(3), 211-227.

Shleifer, A., \& Vishny, R. W. (1997). A survey of corporate governance. The journal of finance, 52(2), 737-783.

The World Bank. (2014). Jordan World Development Indicators: The World Bank.

Yermack, D. (1996). Higher market valuation of companies with a small board of directors. Journal of financial economics, $40(2), 185-211$ 